\title{
Analysis of hairpin RNA transgene-induced gene silencing in Fusarium oxysporum
}

\author{
Ulrike Schumann', Neil A Smith', Kemal Kazan², Michael Ayliffe ${ }^{1}$ and Ming-Bo Wang ${ }^{1 *}$
}

\begin{abstract}
Background: Hairpin RNA (hpRNA) transgenes can be effective at inducing RNA silencing and have been exploited as a powerful tool for gene function analysis in many organisms. However, in fungi, expression of hairpin RNA transcripts can induce post-transcriptional gene silencing, but in some species can also lead to transcriptional gene silencing, suggesting a more complex interplay of the two pathways at least in some fungi. Because many fungal species are important pathogens, RNA silencing is a powerful technique to understand gene function, particularly when gene knockouts are difficult to obtain. We investigated whether the plant pathogenic fungus Fusarium oxysporum possesses a functional gene silencing machinery and whether hairpin RNA transcripts can be employed to effectively induce gene silencing.
\end{abstract}

Results: Here we show that, in the phytopathogenic fungus F. oxysporum, hpRNA transgenes targeting either a $\beta$-glucuronidase (Gus) reporter transgene (hpGus) or the endogenous gene Frp1 (hpFrp) did not induce significant silencing of the target genes. Expression analysis suggested that the hpRNA transgenes are prone to transcriptional inactivation, resulting in low levels of hpRNA and siRNA production. However, the hpGus RNA can be efficiently transcribed by promoters acquired either by recombination with a pre-existing, actively transcribed Gus transgene or by fortuitous integration near an endogenous gene promoter allowing siRNA production. These siRNAs effectively induced silencing of a target Gus transgene, which in turn appeared to also induce secondary siRNA production. Furthermore, our results suggested that hpRNA transcripts without poly $(A)$ tails are efficiently processed into siRNAs to induce gene silencing. A convergent promoter transgene, designed to express poly(A)-minus sense and antisense Gus RNAs, without an inverted-repeat DNA structure, induced consistent Gus silencing in F. oxysporum.

Conclusions: These results indicate that $F$. oxysporum possesses functional RNA silencing machineries for siRNA production and target mRNA cleavage, but hpRNA transgenes may induce transcriptional self-silencing due to its inverted-repeat structure. Our results suggest that $F$. oxysporum possesses a similar gene silencing pathway to other fungi like fission yeast, and indicate a need for developing more effective RNA silencing technology for gene function studies in this fungal pathogen.

Keywords: RNA silencing, Hairpin RNA, Fungi, Polyadenylation, Convergent promoters

\section{Background}

RNA silencing is an evolutionary conserved molecular mechanism that functions in genome defense and stability and also plays an important role in developmental regulation [1-3]. This process is characterized by the production of double-stranded RNA (dsRNA) molecules, which are cleaved by a Dicer-like protein (Dcl) into 20

\footnotetext{
* Correspondence: ming-bo.wang@csiro.au

${ }^{1}$ Commonwealth Scientific and Industrial Research Organisation Plant

Industry, Clunies Ross Street, Canberra ACT 2601, Australia

Full list of author information is available at the end of the article
}

to 25 nucleotide (nt) small RNAs (sRNA) that are subsequently incorporated into an Argonaute protein (Ago) located in the RNA-induced silencing complex (RISC). These sRNAs subsequently enable the RISC to identify complementary mRNA sequences, leading to their targeted degradation by the action of the Ago protein $[4,5]$. However, not all sRNAs are dependent upon Dicer action and several other classes of sRNAs are produced by less well-characterized pathways that are restricted to certain kingdoms of life in some instances [6-10]. In

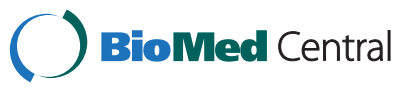


general, the sRNA pathways in most fungal species have been poorly characterized.

One of the better understood sRNA pathways in eukaryotes is the production of micro RNAs (miRNAs). These sRNA species are derived from endogenous genes and regulate developmental processes via post-transcriptional regulation of gene expression [11]. Only recently miRNA-like genes (milRNA) have been identified in Neurospora crassa although their role in this fungal species remains unclear as does their distribution throughout the fungal kingdom [8]. Dicer-independent small interfering RNAs (disiRNAs) and DNA damage-induced Qde2-interacting siRNAs (qiRNAs) have also been identified in Neurospora crassa $[7,8]$ but their occurrence in other fungal species is undetermined. In another well-studied fungus, Schizosaccharomyces pombe (fission yeast) only a single set of silencing machinery genes exists (for example, a single Dcl and Ago), which appear to function in both transcriptional and post-transcriptional silencing pathways [12-14]. Recent analyses of many fungal genome sequences have revealed that some fungal species, such as the Candida species, Saccharomyces cerevisiae and Ustilago maydis, may have lost the RNA silencing machinery genes entirely $[15,16]$. In these fungal species alternative RNA-mediated pathways may be present to regulate gene expression. For instance in Saccharomyces cerevisiae transacting antisense RNAs have been demonstrated to play a role in gene regulation $[17,18]$. These findings suggest that the fungal RNA silencing pathways may have evolved from a single, common ancestral pathway. The function of RNA silencing in fungal development is poorly understood, and mutation of RNA silencing genes resulted in an obvious phenotype only in few fungal species $[19,20]$. In contrast, plant and animal RNA silencing mutants, particularly the miRNA pathway mutants, often display severe developmental defects.

The RNA silencing mechanism has been exploited as a tool for gene functional analysis in many eukaryotic organisms, and expression of hairpin-forming transcripts is now reliably used in many animal and plant species to elucidate gene function. Such hairpin RNA (hpRNA) technologies are also the method of choice for a number of fungal species, particularly since gene knock-out mutants can be difficult to obtain in these organisms [21-24]. Whereas in plants and animals expression of hpRNA generally leads to siRNA production, this is not always the case in fungi. Different hpRNA constructs targeting endogenous genes or transgenes have been tested in several fungal species with varying success (reviewed by $[22,24]$ ). In addition, hpRNA expression in some fungi such as fission yeast resulted in not only post-transcriptional silencing, but also heterochromatin formation $[14,25,26]$.

In this study, we investigated hpRNA transgeneinduced silencing in the fungus Fusarium oxysporum. We provide evidence indicating that, although the RNA silencing machinery exists in this fungus, hpRNA transgenes are usually transcriptionally silenced and ineffective at inducing post-transcriptional silencing of target genes. Our study provides new insights into the RNA silencing mechanisms in this fungal pathogen. It also adds to the current understanding of RNA silencing in fungi and supports the notion that RNA silencing processes are more divergent in fungi than in plants or animals, with different fungi possessing alternative mechanisms that may be species specific.

\section{Results}

\section{Transformation of Fusarium oxysporum with a hairpin RNA construct does not result in silencing of a $\beta$-glucuronidase reporter gene}

In order to develop a reporter gene system for studying RNA silencing in Fusarium oxysporum, the F. oxysporum strain 5176 was transformed with a Gus construct under the regulatory control of the gpdA promoter (Figure 1). Twenty independent lines were isolated and all exhibited varying degrees of Gus activity, as determined by the fluorimetrical assay using 4-methylumbelliferyl- $\beta$ - $D$ glucuronide (MUG) (Figure 2). The majority of Gus lines contained a single T-DNA insertion and no correlation between transgene copy number and Gus activity was apparent (Figure 2).

To study hpRNA-induced silencing, wild type (WT) F. oxysporum, plus three Gus lines that showed low, intermediate and high Gus activities (lines 0-1.3, 0-1.6 and $1-1.3$, respectively), were chosen for super-transformation with a hpRNA Gus (hpGus) construct (Figure 1). As additional controls, these fungal strains were also transformed with another hpRNA construct ( $h p G f p$ ) (Figure 1), and an empty vector control construct (pKR1). All three constructs contain common gpdA promoter and trpC terminator sequences. Multiple independent transformants were obtained for all constructs (Table 1) and mycelial fractions were analyzed for Gus activity. Super-transformants of Gus lines $0-1.3$ and $0-1.6$ showed a mixture of Gus positive and negative colonies regardless of the construct used for transformation. In contrast all, except one, super-transformants of line 1-1.3 maintained Gus activity (Table 1).

The absence of Gus activity in the Gus-negative lines could be due to either silencing of the Gus gene by the hpGus construct, or loss of the Gus target gene by homologous recombination with the super-transformed constructs that share the common promoter and terminator sequences. PCR analysis was undertaken on all $0-1.3$ and 0-1.6 hpGus transformants (additionally, on all 0-1.3 hpGfp and control transformants, as well as on four 0-1.6 control and seven 0-1.6 hpGfp transformants) to determine if the colonies that do not display Gus activity had also lost the Gus transgene. A region unique to the Gus transgene was used for PCR analysis and amplification 

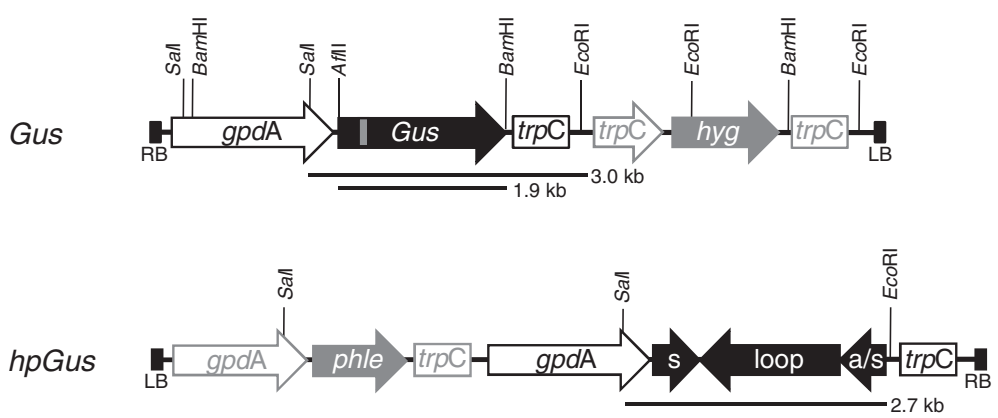

hpGfp

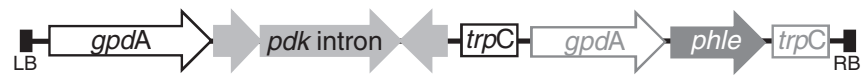

hpFrp

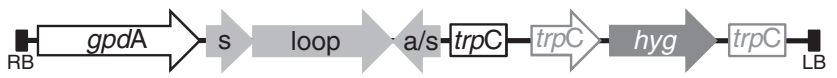

Figure 1 Schematic diagrams (not to scale) of transgenes introduced into Fusarium oxysporum. All Gus-derived sequences are shown in black, except a small region of the Gus ORF represented in grey, which is present in the full length Gus gene but absent in the hpGus constructs. The gpdA promoter is shown as an open arrow, while the transcription terminator sequence trpC is indicated as an open box. Sequences present in hairpin constructs of the Gfp and F. oxysporum Frp1 are shown as light grey regions in each construct, respectively. An intron from the pyruvate dehydrogenase kinase gene ( $p d k)$ is included in the hpGfp gene. The hygromycin phosphotransferase gene (hyg) and Streptomyces verticillius bleomycin gene (phle) were used as selectable markers for F. oxysporum transformation and are shown as dark grey arrows. The positions and expected fragment sizes of restriction endonuclease recognition sites used for DNA blot analyses are indicated.

products were only obtained from transformants that maintained Gus activity (data not shown). This result indicated that the absence of Gus expression was due to loss of the Gus target gene but not due to hpGus-induced silencing. The occurrence of Gus-negative super-transformants in the $0-1.3$ and $0-1.6$ but not the $1-1.3$ background is likely because lines $0-1.3$ and $0-1.6$ only carry a single T-DNA insertion that can be deleted by a single recombination event, whereas line 1-1.3 contains three separate T-DNA insertions, which are unlikely to be all lost by recombination events.
Intact hairpin RNA transgenes do not produce detectable levels of small interfering RNAs in Fusarium oxysporum Several $h p G u s$ and $h p G f p$ transformants of WT and Gus lines $0-1.3$ and $0-1.6$ were analyzed for the presence of siRNAs expected to be derived from processing of the hpRNA transcripts from these transgenes. No line producing Gfp-specific siRNAs was identified out of the nine hpGfp transgenics examined (Table 2). Among the 28 hpGus lines analyzed, the majority (25) did not show siRNA accumulation (Table 2, Figure 3 and [see Additional file 1: Figure S1]). Only three $h p$ Gus lines produced detectable

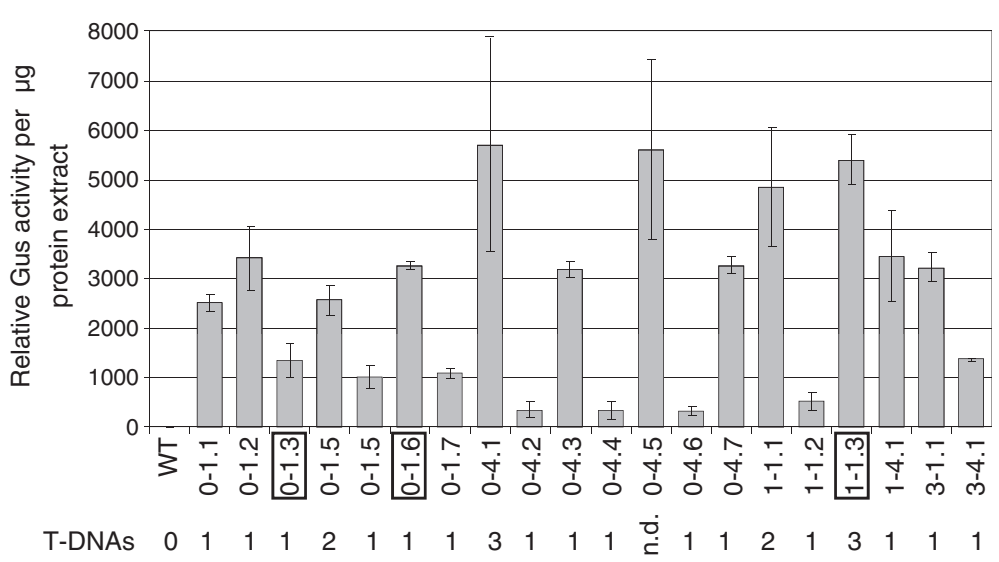

Figure 2 Relative Gus activity of Fusarium oxysporum lines containing the Gus gene. Gus activity was measured by MUG assays of at least three biological replicates of each line. The Y-axis depicts Gus activity per $\mu \mathrm{g}$ of protein extract, while each column on the X-axis represents the activity of a single transgenic line. Standard deviations are indicated on each column. The number of Gus T-DNA insertions present in each line is indicated below the X-axis and was determined by DNA blot hybridization using a probe specific for the hygromycin selectable marker gene. Lines $0-1.3,0-1.6$ and 1-1.3 were used for subsequent hpGus transformation. 
Table 1 Summary of the $\beta$-glucuronidase (Gus) activity of all obtained transformants carrying the hpGus, hpGfp or empty vector control (pKR1)

\begin{tabular}{llll}
\hline Fusarium line & Control (pKR1) & hpGfp & hpGus \\
\hline $\mathrm{WT}^{\mathrm{a}}$ & 11 white & 14 white & 5 white \\
$0-1.3^{\mathrm{a}}$ & 4 white 1 blue & 3 white 9 blue & 1 white 5 blue \\
$0-1.6^{\text {a }}$ & 11 white 1 blue & 12 white 22 blue & 8 white 27 blue \\
$1-1.3^{\text {a }}$ & 0 white 27 blue & 0 white 41 blue & 1 white 26 blue
\end{tabular}

${ }^{a}$ Mycelia fractions were incubated with X-glucuronide solution at $37^{\circ} \mathrm{C}$ overnight and the number of white and blue colonies counted. It is worth noting that only white or dark blue, but not light blue staining was observed.

levels of Gus-specific siRNAs; S5 (in the WT F. oxysporum background), S14, and S34 (both in the 0-1.6 background), hereafter referred to as S5, S14 and S34, respectively. MUG assays indicated that a significant reduction in Gus activity was apparent in S34 extracts along with reduced levels of Gus mRNA (Figure 3).

To further characterize the hpGus lines, genomic DNA was digested with EcoRI and SalI and hybridized with a Gus probe, to detect two conserved fragments corresponding to the Gus and hpGus transgenes, respectively, if these genes were intact (Figure 1). All lines that did not show siRNA accumulation were found to have intact hpGus transgenes (Figure 3 and [see Additional file 1: Figure S1]). However, for S34, which produced significant amounts of siRNAs, both the Gus and hpGus-specific restriction fragments were absent, and instead, a large hybridizing band was observed (Figure 3), indicating that recombination had occurred between the pre-existing Gus transgene locus and the incoming $h p G u s$ transgene. Similarly, recombination also appeared to have occurred in line S14 [see Additional file 1: Figure S1]. As shown below, line S5, which was the only WT hpGus transformant generating Gus-specific siRNAs, contains a distinct T-DNA insertion pattern that allowed transcription of the $h p G u s$ sequence by an endogenous element. Thus, our result showed that intact hpRNA transgenes do not produce detectable amounts of siRNAs, and only transgenic lines with particular T-DNA structures or insertion patterns give rise to siRNAs.

Small interfering RNA accumulation correlates with the presence of double-stranded RNA precursor

It was previously shown that unprocessed hpRNA or dsRNA can be detected using northern blot hybridization in hpRNA lines of plants accumulating siRNAs [27,28]. We therefore used northern blot hybridization to examine if siRNA accumulation in the $h p G u s F$. oxysporum lines was correlated with the expression of dsRNA. RNA samples were treated with RNase One and hybridized for the presence of a $550 \mathrm{nt}$ antisense Gus fragment, equivalent to the size of the hpGus dsRNA arm. The predicted nuclease-resistant RNA fragment was only detected in RNA from lines that produced siRNAs (that is, S34 and S5), and not in lines that produced no detectable siRNAs (Figure 4). However, hybridizing signals were detected in untreated RNA samples of all siRNA-negative lines tested (S23 to S26) (Figure 4). The pattern of these hybridizing bands was equivalent to the pattern observed in plants expressing the same $h p G u s$ transcript [27], indicating that $h p G u s$ is expressed in these fungal lines. However, the level of the hybridizing signals were low compared to the siRNA-generating lines (S34 and S5), suggesting that the hpGus transgene is poorly transcribed in the siRNAnegative lines. The gpdA promoter driving the $h p G u s$ was PCR amplified and sequenced in these siRNA-negative lines and found to be unaltered (data not shown), indicating that the low level of $h p G u s$ transcription was not caused by sequence changes in the promoter. Additionally, DNA blot analysis confirmed the presence and integrity of both hpGus and Gus transgenes in the transformants analyzed (Figure 3 and [see Additional file 1: Figure S1]). These data suggest that the $h p G u s$ transgene is usually subject to transcriptional inactivation in F. oxysporum, generating insignificant amounts of hpRNA precursor for siRNA production, and that the dsRNA precursor detected in lines S5, S14 and S34 are derived from transgenes in a specific

Table 2 Summary of all transformants analyzed regarding the production of siRNAs and rearrangement of the B-glucuronidase overexpression (Gus) and hairpin RNA (hpGus) transgene loci

\begin{tabular}{lccc}
\hline & Strains analyzed & Strains with siRNAs & Strains with Gus locus rearrangement \\
\hline WT hpGus & 5 & $1(\mathrm{~S} 5)^{\mathrm{a}}$ & n.a. \\
0-1.3 hpGus & 5 & 0 & n.d. \\
0-1.6 hpGus & 18 & $2(\mathrm{~S} 14, \mathrm{~S} 34)$ & $3(\mathrm{~S} 13, \mathrm{~S} 14, \mathrm{~S} 34)$ \\
WT hpGfp & 3 & 0 & n.d. \\
0-1.3 hpGfp & 3 & 0 & n.d. \\
0-1.6 hpGfp & 3 & 0 & n.d. \\
WT hpFrp & 9 & 8 & n.a. \\
0-1.6 conP-Gus & 9 & 0 & 0 \\
\hline
\end{tabular}

aines that showed production of Gus-specific siRNAs or rearrangement following super-transformation are indicated in parentheses. n.a. not applicable, n.d. not determined, WT wild type. 

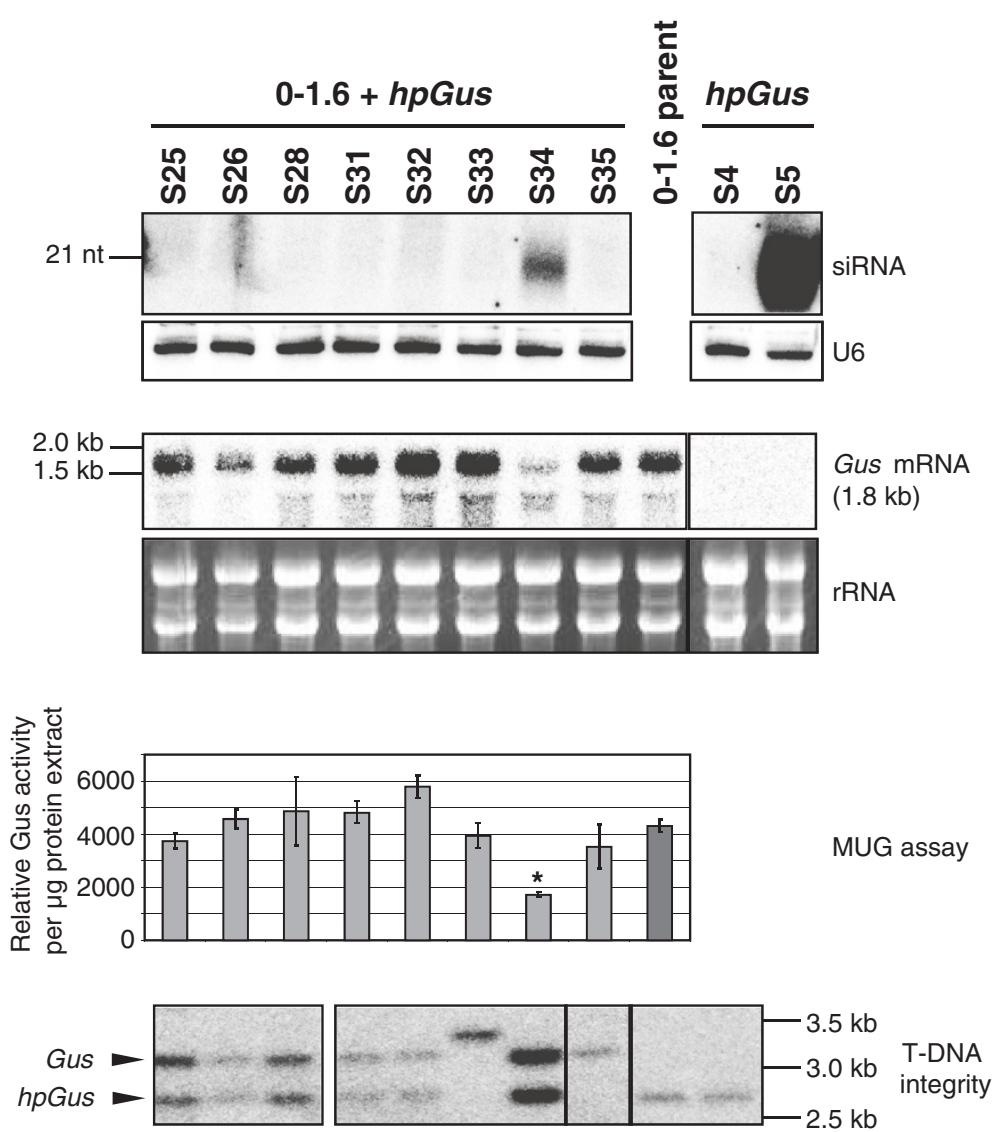

Figure 3 Analysis of $\beta$-glucuronidase hairpin RNA (hpGus) transformants of $\beta$-glucuronidase reporter transgene (Gus) line 0-1.6 and wild type (WT) Fusarium oxysporum. Identification of small RNAs produced in hpGus transgenics by RNA blot analysis (top panel). Total RNA $(15 \mu \mathrm{g})$ was separated on a $17 \%$ polyacrylamide gel and probed for Gus siRNAs. Numbers above each lane designate an independent $h p G u s$ transformant in either 0-1.6 parent (left) or WT (right). As a loading control the same membrane was hybridized with a probe specific for the U6 transcripts and is shown below. RNA blot detection of Gus transcripts in the analyzed transgenic lines (second panel). Total RNA (10 $\mu \mathrm{g}$ ) was hybridized with a probe specific for the region unique to Gus. The position of this unique region in the Gus gene is indicated in Figure 1, for further details see Methods. The ethidium bromide stained ribosomal RNA bands are shown as loading control. Gus activity of 0-1.6 hpGus transformants (third panel) was determined by MUG assay. Shown is the relative Gus activity per $\mu \mathrm{g}$ of protein extract for each transgenic line. Error bars indicate standard deviation of at least two independent biological replicates. MUG assay of line S34, indicated with an asterisk, shows significantly reduced Gus activity (t-test: $p=0.004$ ). DNA blot analysis of hpGus transformants of line $0-1.6$ to determine integrity of the Gus and hpGus transgene loci (bottom panel). Genomic DNAs were digested with EcoRl and Sall and hybridized with a full length Gus probe. Intact hpGus and Gus transgenes produce conserved $2.7 \mathrm{~kb}$ and $3.2 \mathrm{~kb}$ restriction fragments, respectively.

genomic context(s) that enables active hpRNA or dsRNA transcription. These data also indicate that $F$. oxysporum possesses the necessary machineries for processing dsRNA or hpRNA into siRNAs.

\section{A hairpin RNA transgene targeting an endogenous gene does not induce effective silencing in Fusarium oxysporum} In addition to the Gus reporter gene, we also tested the efficacy of hpRNA-induced silencing on an endogenous gene, Frp1. Frp 1 was chosen as a target because F. oxysporum with a loss-of-function mutation of this gene has been shown to be nonpathogenic on tomato [29,30]. Wild type F. oxysporum was transformed with an hpFrp transgene (Figure 1), and nine independent transgenic lines were chosen for subsequent analyses. Both precursor hpFrp transcripts as well as Frp-specific siRNAs were detected in eight of these lines, and levels of the siRNAs and precursor hpRNA were correlated (Figure 5; top and middle panels). Again this indicates that $F$. oxysporum possesses the functional RNA silencing machineries required for siRNA biogenesis. However, the abundance of siRNA again appeared low. Furthermore, a strong reduction in endogenous Frp 1 mRNA levels was not observed in any of the eight lines, presumably as a consequence of the low siRNA levels (Figure 5; bottom panel). Target mRNA analysis using northern blot hybridization detected smaller sized (approximately $1.7 \mathrm{~kb}$ ) hybridizing bands (indicated by an arrow), which were absent in the WT control and in hpFrp line 7 that had no detectable levels of siRNAs (Figure 5; bottom panel). These bands likely represent cleavage products of 


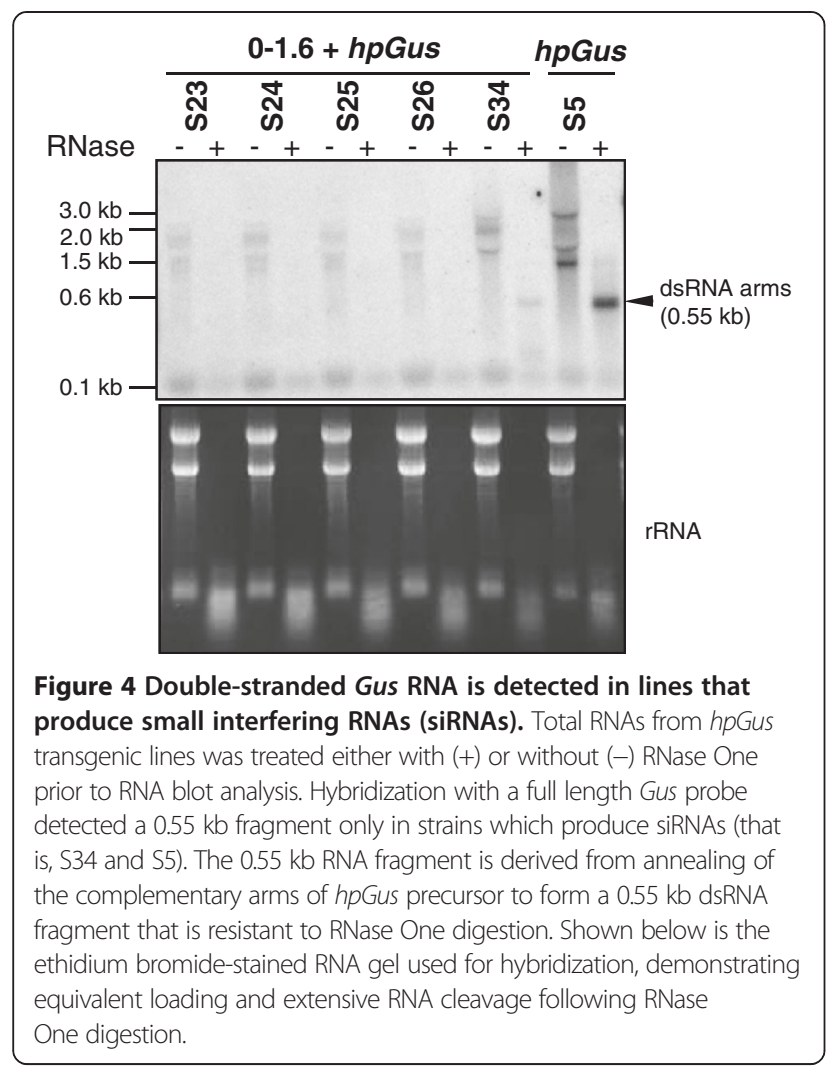

the Frp1 mRNA, suggesting that siRNA-mediated cleavage had occurred, although further experiments are needed to characterize the fragments. Taken together, the data on the hpFrp transgenic lines further suggest that hpRNA transgenes are not highly expressed in F. oxysporum and therefore do not generate sufficient levels of siRNAs required for effective silencing of target genes.

\section{Small interfering RNAs can mediate target messenger RNA downregulation and induce secondary small interfering RNA production in Fusarium oxysporum}

S34 was the only transgenic line identified in which significant downregulation of the target Gus gene was associated with the accumulation of Gus-specific siRNAs (Figure 3). However, DNA blot analysis indicated the absence of both the Gus and hpGus-specific restriction fragments (Figure 3), suggesting that the target Gus gene had undergone rearrangement following super-transformation. Therefore, the reduction in Gus activity in line S34 may be due, in part, to changes in gene expression following this transgene rearrangement rather than a direct result of siRNA-mediated mRNA cleavage.

We therefore investigated if siRNAs are capable of inducing effective silencing in $F$. oxysporum by supertransforming line S5, which showed high levels of Gus-specific siRNAs, with the Gus construct and subsequently measuring the Gus expression levels in the resulting

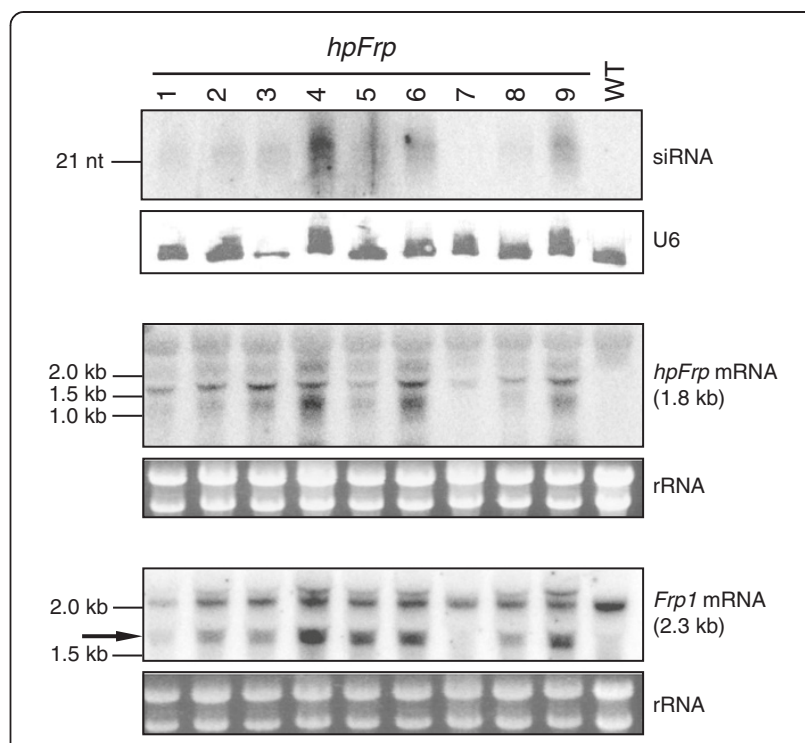

Figure 5 Endogenous genes can be targeted by hpRNA-derived small interfering RNAs (siRNAs). Wild type (WT) Fusarium oxysporum was transformed with a hpRNA construct directed against the endogenous Frp1 gene. Total RNA $(15 \mu \mathrm{g})$ from nine independent transgenic lines was separated on a $17 \%$ polyacrylamide gel and hybridized with a probe specific for Frp1. The hpFrp-derived siRNAs were detected in most lines although the levels are very low (upper panel). The U6 transcripts are shown as loading control. Total RNA $(10 \mu \mathrm{g})$ was separated on an agarose gel and hybridized with an Frp1 sense probe to detect antisense sequences of the hpFrp transgene (middle panel). To detect Frp1 mRNA levels, total RNA $(10 \mu \mathrm{g})$ was hybridized with a probe specific for the $3^{\prime}$ region of the endogenous Frp1 gene, which is not present in the hpFrp gene, detecting $2.3 \mathrm{~kb}$ Frp1 mRNA, but not hpFrp transcripts (lower panel). Ethidium bromide-stained ribosomal RNA is shown as loading control. The additional transcripts detected are likely to be either Frp1 mRNA cleavage products (below the endogenous transcript band) or size mobility shifted endogenous Frp1 likely due to binding of small RNAs (above the endogenous transcript band), as both are not present in the WT sample.

super-transformants. As shown in Figure 6A, with the exception of line S5:Gus W2, all of the eight S5:Gus supertransformants showed greatly reduced Gus expression in comparison to the Gus lines shown in Figure 2. Furthermore, the level of Gus mRNA was in general inversely correlated with the level of Gus-specific siRNAs (Figure 6A).

To exclude the possibility that the low Gus mRNA levels were due to transgene rearrangement, DNA blot analysis was performed. Five out of the eight S5:Gus supertransformants contained the predicted Gus and $h p$ Gus-specific restriction fragments (Figure 6A). These five supertransformants showed low levels of Gus activity as well as low levels of Gus mRNA along with the presence of siRNAs, indicating that the reduced Gus expression is due to siRNAmediated mRNA cleavage. To demonstrate that RNA silencing was occurring in these lines, Gus mRNA cleavage products were cloned from RNA of line S5:Gus W4 using 5' RACE (see Methods). Several individual fragments were 


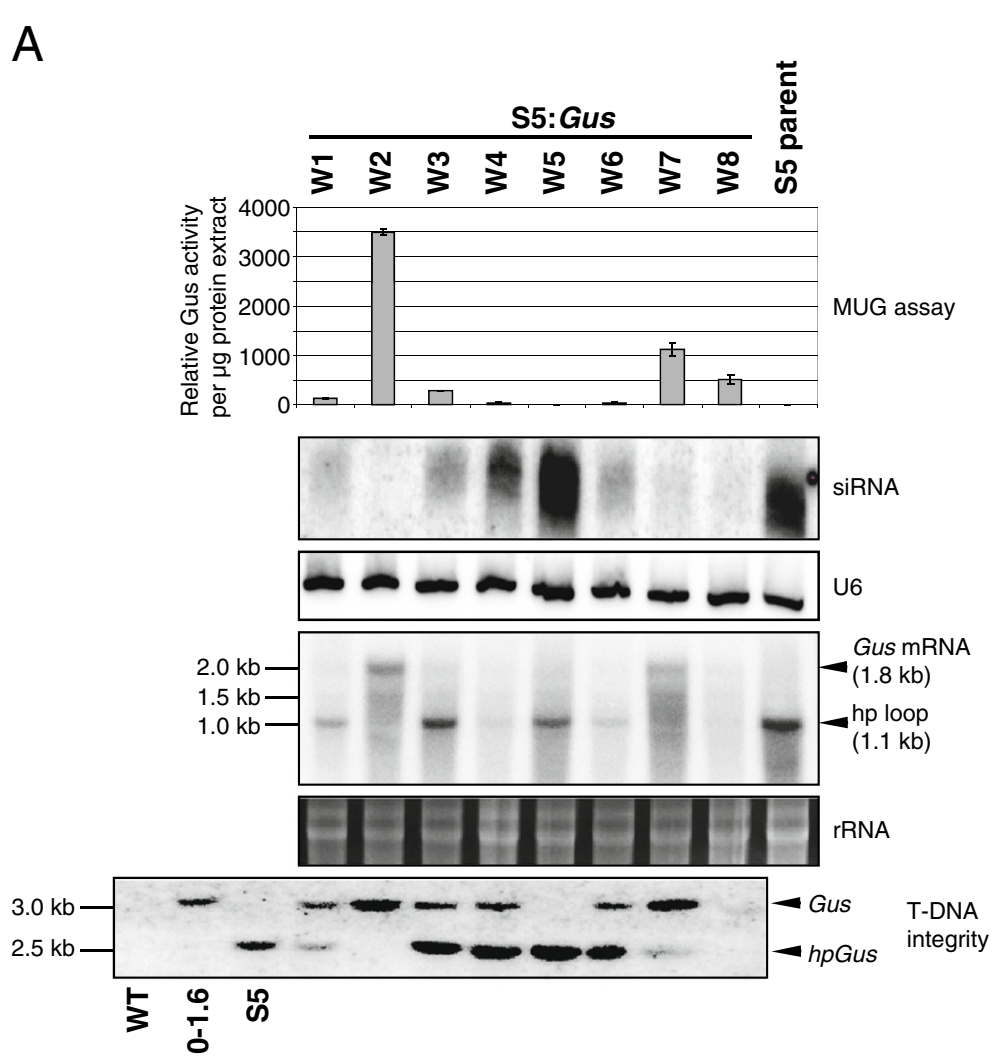

B

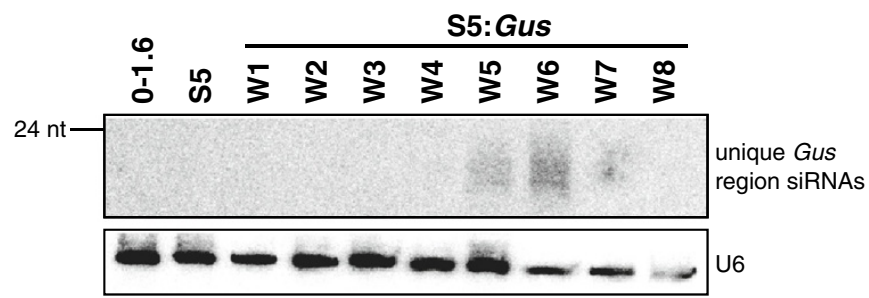

Figure 6 -glucuronidase hairpin RNA (hpGus)-derived small interfering RNAs (siRNAs) can mediate target transcript downregulation. (A) Strain S5, which contains the hpGus transgene and produces siRNAs (see Figure 3), was super-transformed with the Gus transgene to obtain S5:Gus lines W1 to W8. Relative Gus activity was determined by MUG assay (top panel). The mean of at least two independent biological replicates is shown with error bars representing the standard deviation. The second panel shows RNA blot analysis of $15 \mu \mathrm{g}$ of total RNA hybridized with a full length Gus probe to detect small RNAs. The U6 transcripts are shown as loading control. Expression levels of the Gus and hpGus transgenes are shown in the fourth panel. Total RNA $(10 \mu \mathrm{g})$ was hybridized with a full length Gus probe, detecting the $1.8 \mathrm{~kb}$ transcript derived from the Gus transgene and the $1.1 \mathrm{~kb}$ fragments corresponding to the single stranded loop region of the hpGus transcript. Ethidium bromide-stained ribosomal RNA bands are shown as loading control. DNA blot analysis was performed to determine transgene integrity (bottom panel). Genomic DNA was restricted with EcoRl and Sall, and hybridized with a full length Gus probe. Restriction fragments corresponding to the hpGus (2.7 kb) and Gus transgenes (3.2 kb) are present in most lines, indicating that both transgenes remain intact. (B) Secondary siRNAs are produced in some of these lines. Total RNA $(15 \mu \mathrm{g})$ from S5:Gus lines W1 to W8 were resolved on 17\% polyacrylamide and hybridized with a probe specific for the unique region that is present only in the Gus but not the hpGus transcript (see Figure 1 and Methods for details). Low levels of Gus-specific siRNAs were identified in lines W5 to W7. The U6 transcript is shown as loading control.

sequenced and found to represent four distinct cleavage sites within the Gus mRNA, indicating that siRNAmediated target mRNA cleavage had occurred (see below and Table 3).

It is noteworthy that in all five lines that contained both the Gus and $h p G u s$ transgenes, the levels of siRNAs were lower than in the initial parental line S5. This reduction in siRNA level implies that the presence of target mRNA may destabilize complementary small RNAs in F. oxysporum. This possibility is consistent with the observations that expression of miRNA target mimic transcripts reduces the level of the respective miRNA in 
Table 3 Cleavage products obtained by 5' RACE of RNA samples from line S5:Gus W4

\begin{tabular}{cc} 
Cleavage site in Gus mRNA (nt) $^{\mathbf{c}}$ & Number of fragments sequenced $^{\mathbf{d}}$ \\
\hline $80 \mid 81^{\mathrm{b}}$ & 3 \\
$428 \mid 429^{\mathrm{b}}$ & 5 \\
$548 \mid 549^{\mathrm{b}}$ & 7 \\
$587 \mid 588^{\mathrm{a}}$ & 6 \\
$623 \mid 624^{\mathrm{a}}$ & 3 \\
$778 \mid 779^{\mathrm{a}}$ & 1
\end{tabular}

Gus, $\beta$-glucuronidase, nt nucleotides.

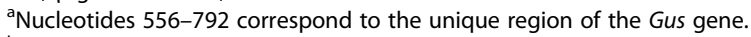

${ }^{\mathrm{b}}$ The first 555 nucleotides of the Gus gene were used to construct the double stranded arm region of the hpGus gene. 'Shown are the nucleotide (nt) numbers of the Gus gene between which cleavage had occurred and dhow often this fragment was recovered.

plants [31] and that miRNA decay rates are dramatically enhanced by the presence of highly expressed target genes in human cells [32].

F. oxysporum S5:Gus transformants were also used to investigate whether an amplification mechanism, through which secondary siRNAs are generated, exists in this fungal species. A probe that is specific for the unique region of the Gus transgene, and therefore does not recognize the $h p G u s$ sequence (see Methods), was hybridized to RNA from the eight S5:Gus lines. Low levels of small RNAs derived from this unique region of the Gus transgene were detected in the S5:Gus lines W5 and W6 (Figure 6B). These small RNA species were derived from sequences outside of the $h p G u s$ transgene and are therefore likely to be generated by an amplification mechanism. The lack of such siRNAs in the other S5:Gus lines could be explained by different transgene insertions having different susceptibility to silencing amplification as observed for transgenes in plants (for example, [33]). However, this result does not exclude the possibility that the small RNAs detected in lines W5 and W6 were generated due to specific integration patterns of the newly introduced Gus transgene alone, but independently of the pre-existing $h p G u s$ transgene.

\section{Hairpin RNA is transcribed from recombined promoters}

As described above, lines S14 and S34 each contained a single, aberrant restriction fragment in DNA blot experiments, when hybridized with a Gus-specific probe, whereas the conserved Gus and hpGus-specific fragments were absent (Figure 3 and [see Additional file 1: Figure S1]). In each line this unique restriction pattern is likely to be a consequence of $h p G u s$ transgene integration within the Gus transgene, such that Gus activity was lost in S14, but retained in S34, and both strains were capable of producing siRNAs (Figure 3 and [see Additional file 1: Figure S1]). To determine the nature of this insertion event in line S34, a lambda phage library was created and a phage colony which contained the entire Gus locus isolated and sequenced in its entirety.

Sequencing indicated that line S34 carried an inverted repeat of the Gus sequence created by integration of the gpdA promoter, together with the upstream half of the dsRNA arm of the $h p G u s$ construct, in antisense orientation downstream of the full-length Gus ORF (Figure 7A). This rearrangement is consistent with a single $3.2 \mathrm{~kb}$ Sall fragment being present in genomic DNA of this line upon DNA blot hybridization with a Gus specific probe (Figure 3). Given the rearrangements apparent at this locus and the significant level of Gus activity, it is likely that the RNA is transcribed by the gpdA promoter of the resident Gus target gene, and that this RNA encodes both, a functional Gus protein and a hpRNA template for siRNA production. Presumably this transcription is inefficient, explaining the comparatively low siRNA and Gus transcript levels in this line (Figure 3).

Next we investigated why hpRNA was efficiently transcribed in line S5. As the gpdA promoter of the $h p G u s$ transgene generally did not produce high levels of $h p G u s$ RNA and Gus-specific siRNAs (Figure 3 and [see Additional file 1: Figure S1]), it was possible that siRNAs present in line S5 were derived from an endogenous promoter downstream of the T-DNA insertion site (Figure 7A). RNA blot analysis using a probe specific for hpGus precursor transcripts detected a smear of hybridizing signals in S5 RNA (Figure 4), indicating the expression of $h p$ Gus RNA of varying size. When RNAs were hybridized with a probe specific for antisense $\operatorname{tr} p \mathrm{C}$ terminator sequences (Figure 1, Figure 7A), multiple transcripts were detected in line S5, which were absent in other $h p G u s$ transformants (Figure 7B). This indicated that transcription occurred in the opposite orientation to the gpdA promoter of the hpGus transgene, presumably by an endogenous promoter adjacent to the T-DNA insertion site. Several attempts of tail-PCR were made to clone the flanking endogenous sequence but were unsuccessful. The presence of multiple hybridizing bands is likely due to the absence of a transcription termination signal that can stop transcription from the endogenous promoter. Similarly, when RNAs were hybridized with a probe that would only detect sense $h p$ Gus loop sequences (hence indicating transcription from the opposite direction), a one-kilobase fragment, consistent with the size of a processed sense loop transcript, was present in line S5 RNA, but not in RNAs of other hpGus transformants (Figure 7C). Such full-length processed loop fragments are typical of hpRNA expressed in plants [28]. Thus, in both lines S34 and S5, hpRNA appears to be transcribed by an endogenous promoter gained through specific transgene integration events from a resident transgene or endogenous gene, but not by the transgenic promoter of the original hpGus transgene cassette. 

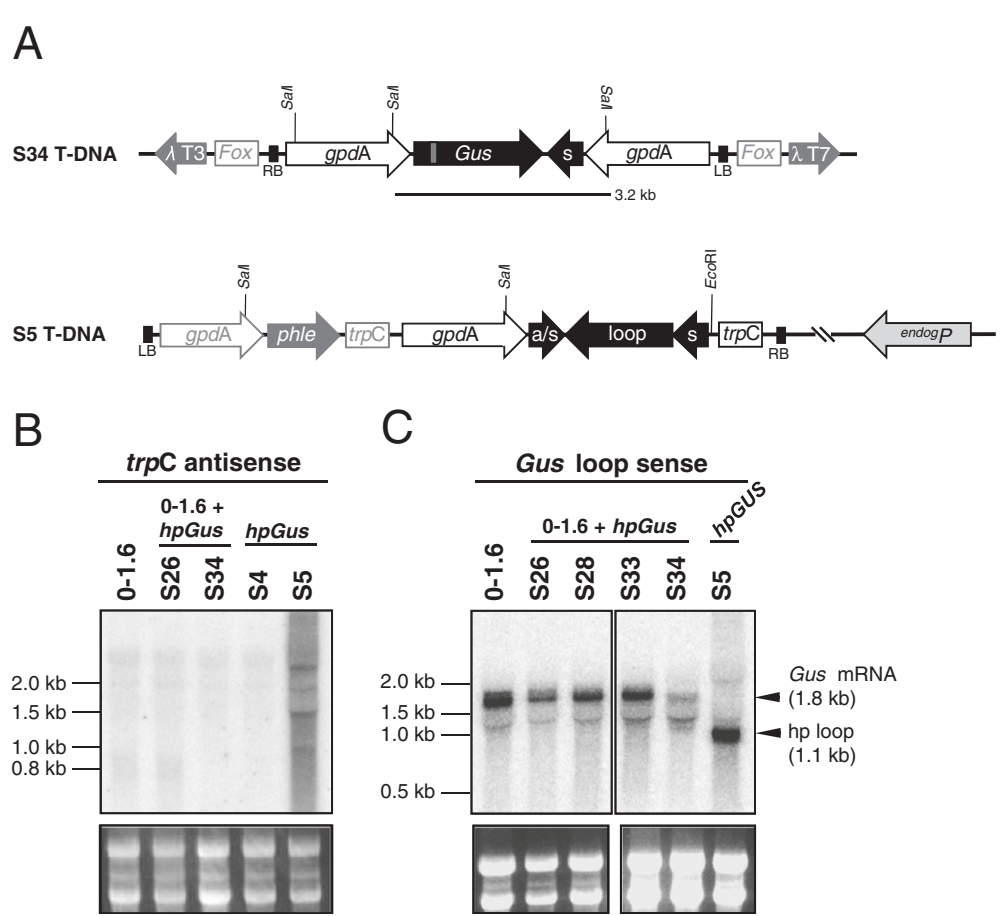

Figure 7 Analysis of the transgene re-arrangments in Fusarium oxysporum lines S34 and S5. (A) Schematic diagrams (not to scale) of the transgenes in F oxysporum lines S34 and S5. The structure of the S34 locus was determined by sequencing of a lambda phage clone containing this entire region and was derived likely by recombination between the pre-existing Gus transgene and an incoming hpGus transgene, such that the full length Gus ORF is followed by the 550 nt antisense Gus arm and the gpdA promoter, both derived from the hpGus transgene. The resulting hairpin-like Gus sequence is flanked by convergent gpdA promoters. Details of both transgenes prior to the recombination event are shown in Figure 1. Fox, F. oxysporum genomic sequences; $\lambda T 3$ and $\lambda T 7$, lambda phage T3 and T7 RNA polymerase binding sites. (B) The hpGus transcripts in strain S5 were likely derived from an endogenous promoter 3' of the T-DNA insertion site. Total RNA (10 $\mu \mathrm{g})$ from the Gus 0-1.6 parent (left lane), 0-1.6 hpGus lines (middle two lanes) and WT hpGus lines (right two lanes) was hybridized with a probe detecting antisense trpC terminator sequences. $\operatorname{Trp} C$ antisense sequences were only present in line $\mathbf{S}$, suggesting that these transcripts are produced by an endogenous promoter located downstream of the hpGus integration site. (C) Hybridization of total RNA (10 $\mu \mathrm{g})$ with an antisense Gus probe specific for the loop region of the hpGus transgene, detecting transcripts that contain sense Gus sequences. Transcripts derived from the resident Gus transgene (1.8 kb) were detected in all samples except S5, which does not carry the Gus transgene. The $1.1 \mathrm{~kb}$ Gus sequence detected only in RNA of S5, corresponds to the hairpin loop region, likely produced by dicer processing of a correctly folded hairpin transcript.

\section{Consistent induction of RNA silencing by a convergent promoter construct}

Our analyses of the $h p G u s$ lines raised two possibilities. First, hpRNA transgenes in the $F$. oxysporum genome are highly susceptible to transcriptional inactivation, possibly due to the inverted repeat DNA structure, resulting in lack of siRNA production. Second, based on the analyses of lines S34 and S5, dsRNA transcribed from a terminatorless transgene, which would lack polyadenylation, may be more efficiently processed into siRNAs. To test these possibilities, a construct was generated (conP-Gus; Figure 8A), which contained two convergent promoters that bidirectionally transcribe a $1.1 \mathrm{~kb}$ sequence of the Gus ORF to generate dsRNA. This construct contained no terminator sequences and therefore both sense and antisense Gus transcripts, were expected to lack poly(A) tails. The construct was transformed into $F$. oxysporum line $0-1.6$, which contains an actively expressed Gus gene.
All nineteen independent $F$. oxysporum lines carrying the conP-Gus construct analyzed showed a significant reduction in Gus activity as determined by MUG assays, in addition to exhibiting greatly reduced Gus mRNA levels (Figure 8A). No evidence of transgene rearrangement was observed by DNA blot analysis in any of these lines (data not shown). The observed reduction in Gus activity and Gus mRNA levels in conP-Gus lines is therefore likely to be a consequence of dsRNA-induced RNA silencing. Consistent with this, the Gus sequence of the conP-Gus construct was found to be transcribed in both sense and antisense orientation by the convergent promoters (Figure 8B), indicating the likelihood of Gus dsRNA formation. The uniform expression of the sense and antisense RNAs across the two independent lines analyzed, suggests that this transgene is not as prone to transcriptional inactivation as the $h p G u s$ transgene, possibly due to a lack of the inverted repeat DNA structure. 


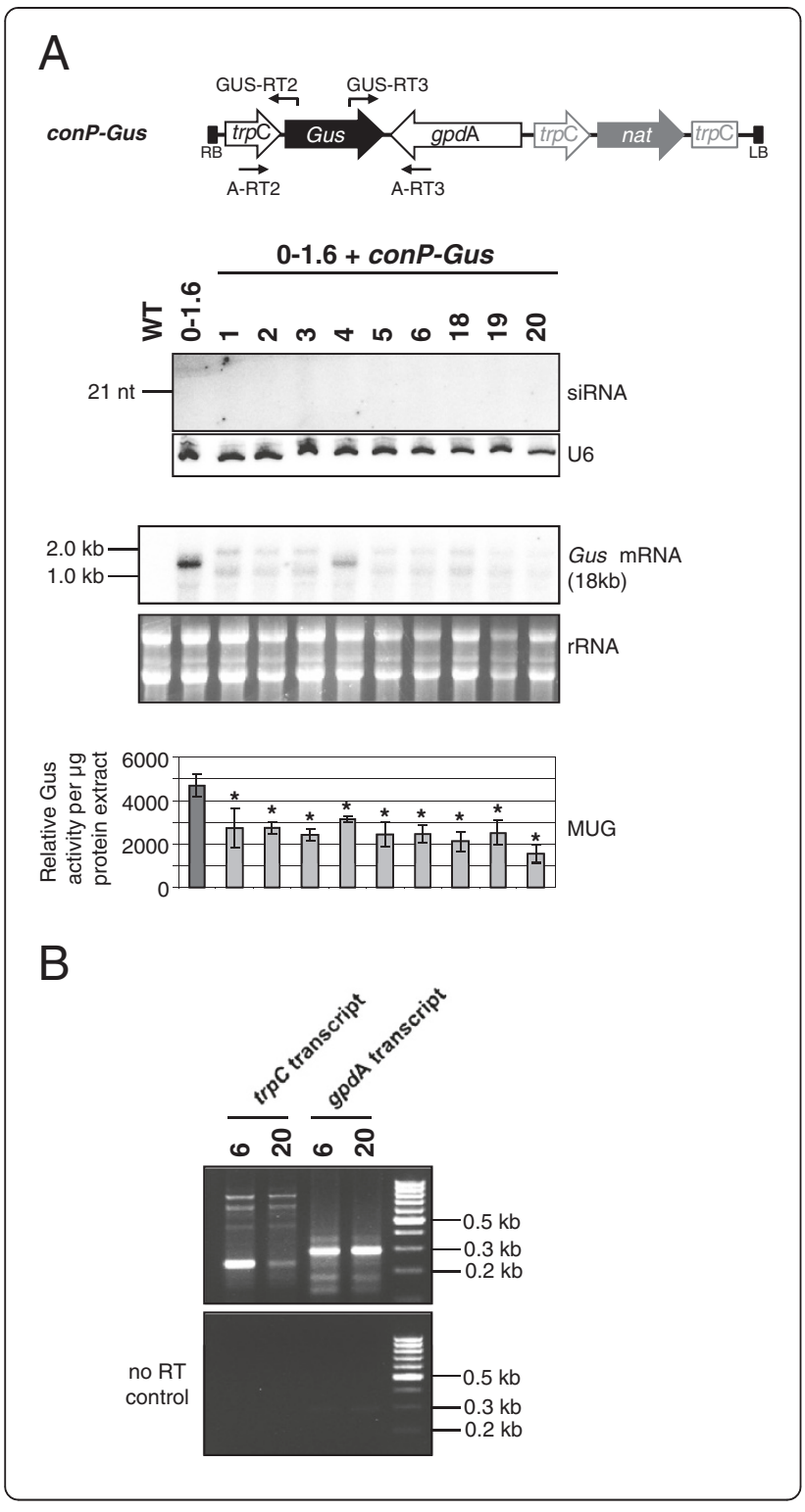

However, Gus-specific siRNAs could not be clearly detected in any of the conP-Gus transformants (Figure 8A), even after small RNA enrichment [see Additional file 1: Figure S3], presumably because siRNA levels were extremely low. This implies that in vivo formation of dsRNA through annealing of two separate RNA transcripts is less efficient than through folding of two complementary sequences within the same hpRNA transcript. This is consistent with the observation in plants where co-expression of sense and antisense RNAs from two separate transcription units is generally less effective in inducing target gene silencing [34].

As a comparison to conP-Gus, we also transformed line 0-1.6 with a construct that would allow transcription of a sense Gus sequence with a poly-A tail plus convergent
Figure 8 Analysis of $\beta$-glucuronidase (Gus) 0-1.6 transgenics carrying the conP-Gus constructs. (A) Schematic diagram (not to scale) showing details of the T-DNA region of the conP-Gus construct. The Gus sequence consists of the 3' $1.1 \mathrm{~kb}$ of the Gus ORF and is shown in black. The convergent promoters driving transcription are shown as open arrows. The Streptomyces noursei nouseothricin gene was used as selectable marker (clonNAT, Werner BioAgents, Germany) and is shown in grey. Total RNA

$(15 \mu \mathrm{g})$ was separated on $17 \%$ polyacrylamide gels and probed for Gus-derived small interfering RNAs (siRNAs) (upper panel). No small RNA species were detected in any of these lines. U6 transcripts are shown as loading control. To determine Gus transcript levels, total RNA $(10 \mu \mathrm{g})$ was separated by agarose gel electrophoresis and hybridized with a probe specific for the region unique to the Gus transgene, not present in the conP-Gus gene (middle panel). Most lines show reduced Gus mRNA levels. Detected fragments are likely either cleavage products (below the Gus fragment) or size shifted due to siRNA binding (above the Gus fragment). Ribosomal RNA bands are shown as loading control. All transgenic lines were analyzed for Gus activity, which was carried out by MUG assay in at least two independent biological replicates (bottom panel; error bars show standard deviation). All conP-Gus transformants showed significantly reduced Gus activity (*t-test: $P<0.003$ ). (B) Gus transcription occurred from both transgenic promoters. Total RNA (500 ng) was reverse transcribed using Gus-specific primers Gus-RT2 or Gus-RT3 (see schematic). Fragments were amplified from cDNA or no RT control RNA using primers Gus-RT2 and A-RT2 (trpC transcript), or Gus-RT3 and A-RT3 (gpdA transcript). Products were separated on a $2 \%$ agarose gel. Fragments of the correct size were obtained for both promoters, indicating that dsRNA could be produced in these lines.

transcription of an antisense Gus sequence without a terminator sequence (conP-Gus-ter; [see Additional file 1: Figure S2A]). However, we could not detect transcription past the $\operatorname{trp} \mathrm{C}$ terminator sequence from the $g p d \mathrm{~A}$ promoter [see Additional file 1: Figure S2B] possibly due to a bi-directional transcription termination property of the trpC terminator. Also, no significant reduction in Gus mRNA levels or Gus activity was observed in these transgenic lines [see Additional file 1: Figure S2C]. This result suggests that the transcription of both sense and antisense Gus RNA is required for the observed Gus silencing with the conP-Gus construct. The lack of antisense Gus transcription by conP-Gus-ter construct prevented us from examining if the addition of ploy(A) might inhibit the silencing-inducing effect of the converging construct.

\section{Discussion}

The results presented in this paper demonstrate that unlike Ascomycete fungi (reviewed by $[22,24]$ ) hpRNA transgenes do not reliably lead to the production of siRNAs in F. oxysporum. Neither hpGus nor $h p G F P$ transgenes were found to produce siRNAs in this species. Transformation with an hpRNA construct targeting the endogenous Frp1 gene did lead to siRNA production in the majority of analyzed transformants; however, the abundance of siRNAs was low and no strong silencing 
of the Frp1 gene was observed. In Neurospora crassa, the arm length of the hpRNA constructs was critical for efficient silencing [35]; however this was not a factor affecting the $h p G u s$ and $h p G f p$ constructs used in this study, which were well within these design parameters. The inclusion of a spliceable intron into the hairpin loop region, which has been shown to promote efficient siRNA processing in plants [36], also did not induce siRNA production in F. oxysporum (Table 2).

However, our results indicate that $F$. oxysporum does possess functional RNA silencing machineries which process hairpin precursor transcripts into siRNAs that target homologous mRNA for cleavage. Introduction of the $h p F r p$ transgene led to production of siRNAs in the majority of lines, resulting in cleavage of the target $\operatorname{Frp} 1$ mRNA, although the level of silencing is not high. Similarly siRNAs could be produced from $h p$ Gus RNA transcribed from an endogenous promoter (as in line S5) or a promoter of an actively expressed resident transgene (as in line S34). Furthermore, siRNAs in line S5 were capable of inducing effective silencing of the super-transformed Gus gene. Thus, F. oxysporum contains RNA silencing machineries required for both dsRNA processing and for siRNA-directed silencing, which is consistent with the identification of multiple Dicer and Argonaute-like genes from the Fusarium oxysporum strain 4287 genome using bioinformatics [see Additional file 1: Table S2].

A question is therefore why hpRNA transgenes investigated here were not effective at generating siRNAs and inducing silencing in $F$. oxysporum. Three independent studies in S. pombe utilizing the Ura4 gene as a target have shown that hpRNA transgenes can direct both heterochromatin formation (transcriptional gene silencing) and posttranscriptional gene silencing, depending on the location of the targeted gene within the host genome $[14,25,26]$. This suggests that an hpRNA transcript in fission yeast can activate two independent gene silencing pathways, transcriptional and post-transcriptional. It is noteworthy that fission yeast contains only a single set of RNA silencing proteins which mediate both heterochromatin formation and posttranscriptional silencing, suggesting that these two pathways are mechanistically linked. It is possible that hpRNA also induces transcriptional silencing in $F$. oxysporum, which can target the hpRNA transgene itself to cause transcriptional self silencing. A recent study in plants has indicated that hpRNA transgenes are subject to self silencing through siRNA-directed DNA methylation, a plant-specific transcriptional gene silencing pathway [37]. Northern blot analysis indicated that the $h p G u s$ and $h p F r p$ transgenes were poorly transcribed in the transgenic $F$. oxysporum lines, suggesting that they were transcriptionally silenced. However, a DNA methylation analysis of the $h p G u s$ transgene failed to detect any methylation at either locus (data not shown), suggesting that DNA methylation is not involved in the transcriptional silencing, but that histone modification might be responsible as in the case of transcriptional silencing in fission yeast [14].

While the strong and constitutive gpdA promoter of the hpRNA constructs failed to confer high levels of hpRNA and siRNA expression in F. oxysporum, the $h p G u s$ RNA was efficiently transcribed by an endogenous element, presumably the promoter of an actively expressed endogenous gene, which was accidentally acquired by T-DNA integration. Furthermore, the gpdA promoter of the resident Gus target gene was also able to transcribe the hpRNA formed by DNA rearrangement between the Gus and the $h p G u s$ transgenes. This implies that promoters of newly introduced hpRNA transgenes are more susceptible to transcriptional silencing than those of genes already residing in the genome which are actively expressed. Consistent with this possibility, transgene promoters are highly susceptible to hpRNA-induced transcriptional inactivation in plants whereas endogenous promoters are usually resistant to hpRNA-induced transcriptional silencing [11].

Our results suggest that non-polyadenylated dsRNA is efficiently processed by Dicer into siRNAs in $F$. oxysporum. Lines S5 and S34 both produced small RNA species and both lacked transcription terminators for hpRNA transcription and are therefore likely to produce non-polyadenylated precursor transcripts. Furthermore, bi-directional transcription of a Gus sequence from convergent promoters (conP-Gus) without transcription terminators consistently downregulated Gus mRNA levels. It is possible that Dicer processing of dsRNA occurs in the nucleus of F. oxysporum, and therefore nonpolyadenylated dsRNA is a preferred substrate because of its possible retention in the nucleus after transcription. However, further work is needed to test this idea. Also, as no siRNAs were detectable in plants transformed with the convergent promoter construct, it cannot be ruled out that an alternative, siRNA-independent, mechanism may account for the conP-Gus-induced gene silencing.

\section{Conclusions}

We demonstrate here that RNA silencing machineries exist in $F$. oxysporum, however conventional hpRNA transgenes are not effective at inducing gene silencing due to poor transcriptional activity of the transgene. Convergent promoter transgenes are capable of inducing gene silencing, but with low silencing efficiency. Future studies should focus on achieving potent and consistent RNA silencing in F. oxysporum by preventing transcriptional silencing of hpRNA or other types of dsRNA transgenes. Alternatively, the transcriptional silencing mechanism may be exploited to develop effective gene silencing technology in F. oxysporum. 


\section{Methods}

\section{Media and solutions}

All chemicals and media were obtained from either Sigma (Sydney, NSW, Australia) or BDH (VWR International, Radnor, PA, USA). Hybond membranes were obtained from Amersham Biosciences (GE Healthcare Australia, Rydalmere, NSW, Australia). Potato Dextrose Agar (PDA, Sigma) and Potato Dextrose Broth (PDB, Sigma) were both used at half strength and PDA was supplemented with $12.5 \mathrm{~g} / \mathrm{l}$ agar. PDA or PDB containing $0.1 \mathrm{M}$ Tris$\mathrm{HCl} \mathrm{pH} 8$ was used for phleomycin selection. Luria Bertani (LB) medium contained per liter $5 \mathrm{~g}$ yeast extract, $5 \mathrm{~g}$ tryptone and $10 \mathrm{~g} \mathrm{NaCl}$, supplemented with $15 \mathrm{~g} / \mathrm{l}$ agar for solid media. Induction Medium contained $10 \mathrm{mM}$ $\mathrm{KH}_{2} \mathrm{PO}_{4}, 10 \mathrm{mM} \mathrm{K}{ }_{2} \mathrm{HPO}_{4}, 2.5 \mathrm{mM} \mathrm{NaCl}, 4 \mathrm{mM}\left(\mathrm{NH}_{4}\right)$ ${ }_{2} \mathrm{SO}_{4}, 0.5 \%$ glycerol, $9 \mu \mathrm{M} \mathrm{FeSO}_{4}, 10 \mathrm{mM}$ glucose, $40 \mathrm{mM}$ MES buffer $\mathrm{pH}$ 5.3, $0.7 \mathrm{mM} \mathrm{CaCl}$ and $2 \mathrm{mM} \mathrm{MgSO}_{4}$. Induction agar was the same as induction medium except it contained $5 \mathrm{mM}$ glucose and $0.2 \mu \mathrm{M}$ acetosyringone. SDS/BSA hybridization solution contained per liter $70 \mathrm{~g}$ SDS, $10 \mathrm{~g}$ BSA, 122.4 g Na $\mathrm{NPO}_{4} \times 12 \mathrm{H}_{2} \mathrm{O}, 25 \mathrm{~g}$ $\mathrm{NaH}_{2} \mathrm{PO}_{4}$ and $10 \mathrm{mM}$ EDTA pH 8.0. Northern hybridization solution contained $50 \%$ formamide, $1 \%$ SDS, $5 \times$ SSPE buffer ( $3 \mathrm{M} \mathrm{NaCl}, 0.2 \mathrm{M} \mathrm{NaH} \mathrm{PO}_{4}$ and $0.02 \mathrm{M}$ EDTA pH 7.4) and $5 x$ Denhardt's solution (2\% Ficoll 400, 2\% PVP and 2\% BSA). DNA extraction buffer contained $0.5 \mathrm{M} \mathrm{NaCl}, 0.1 \mathrm{M}$ Tris- $\mathrm{HCl} \mathrm{pH} 8.0$ and $50 \mathrm{mM}$ EDTA $\mathrm{pH}$ 8.0. protein extraction buffer contained $50 \mathrm{mM}$ $\mathrm{NaPO}_{4}, 10$ mM EDTA pH 7.0, 0.1\% Triton X-100, 0.1\% Sarkosyl and $10 \mathrm{mM}$ ß-mercaptoethanol. MUG assay buffer was protein extraction buffer containing $2 \mathrm{mM}$ 4-methylumbelliferyl-ß-D-glucoronide hydrate (MUG).

\section{Growth and storage of Fusarium and bacteria}

Fusarium oxysporum f.sp. conglutinans strain 5176 was grown at $28^{\circ} \mathrm{C}$ in either liquid PDB shaking at $200 \mathrm{rpm}$ or on solid PDA. For long-term storage of Fusarium, conidia of $1 \mathrm{ml}$ from a liquid culture were collected by centrifugation, suspended in $500 \mu \mathrm{l}$ of $15 \%$ glycerol and stored at $-80^{\circ} \mathrm{C}$.

Agrobacterium tumefaciens strain AGL0 was used for Fusarium transformation as it produced the largest number of transformants compared to other strains. AGL0 was grown at $28^{\circ} \mathrm{C}$ in liquid $\mathrm{LB}$ medium or on solid LB plates supplemented with $20 \mu \mathrm{g} / \mathrm{ml}$ rifampicin and the appropriate antibiotic to select for the binary vector. $E$. coli strain DH5 $\alpha$ was used for construction, propagation and amplification of plasmid DNA and was grown in liquid or on solid LB medium supplemented with the appropriate antibiotic at $37^{\circ} \mathrm{C}$.

Creation of the $\beta$-glucuronidase (Gus) expression cassette For all primer sequences see Additional file 1: Table S1. The gpdA promoter sequence [Genbank Z32524] was amplified using the gpdA-F1 primer containing a terminal EcoRI site and the gpdA-R1 reverse primer carrying the restriction enzyme recognition sites AfeI, AflII, EcoRV, XbaI, HindIII and KasI. Similarly, the trpC terminator sequence [Genbank X02390] was amplified using the $\operatorname{trp} \mathrm{C}-\mathrm{R} 1$ reverse primer containing a terminal $K p n I$ site and the trpC-F1 forward primer carrying the enzyme recognition sites XbaI, HindIII, KasI, HpaI, ClaI and BamHI. The two fragments were combined into a single construct by overlapping PCR, thus creating a multiple cloning site (MCS) located between the gpdA promoter and $\operatorname{trpC}$ terminator. The fusion fragment was ligated into pGEM-T Easy (Promega, Madison, WI, USA), verified by sequencing and termed pUS1.

The coding sequence of the bacterial UidA (Gus; [Genbank AAC74689]) gene was ligated into the EcoRV site of plasmid pUS1 and the entire cassette excised using EcoRI. The overhangs were end-filled with Pfu (Promega) polymerase and the fragment ligated into the EcoRV site of the fungal binary vector pPZPHyg [38]. The resulting vector was verified by sequencing and termed pPZPHyg-Gus (Figure 1).

\section{Creation of hairpin RNA silencing constructs}

The fungal binary vector pKR1 was based on vector pRW1p [39], which was extended to contain a MCS flanked by the $g p d \mathrm{~A}$ promoter and $\operatorname{trp} \mathrm{C}$ terminator. Using $P f u$ polymerase and the primer pair trpC-F2 and $\operatorname{trpC}-\mathrm{R} 2$, the $\operatorname{trp} \mathrm{C}$ terminator was amplified by PCR and ligated into the EcoRV site of vector pBC sk + (Stratagene), creating $\mathrm{pBC}-\operatorname{trpC}$. A SpeI recognition site was introduced into pAN9-1 (a derivative of vector pAN7-1 [40]) immediately 3 ' of the gpdA promoter by sitedirected mutagenesis. The gpdA promoter was then excised using EcoR1 and SpeI, end-filled using Pfu polymerase and ligated into the SmaI site of pBC-trpC to create $\mathrm{pBC}$-gpdA:trpC. The gpdA:trpC fragment was then removed from $\mathrm{pBC}-g p d \mathrm{~A}: \operatorname{trp} \mathrm{C}$ using $\mathrm{Xba \textrm {I }}$ and HindIII and end-filled. The vector pRW1p was restricted with EcoRI and BamHI, end-filled and re-ligated to remove several endonuclease recognition sites. The vector was then digested with $\mathrm{XbaI}$ and HindIII, end-filled and ligated with the gpdA:trpC fragment from plasmid pBCgpdA:trpC to create the vector pRW1p-gpdA:trpC. The lacZ gene was PCR amplified with Pfu polymerase using the primers lacZ-F and lacZ-R, which carried the recognition sites of 14 unique restriction enzymes, thus creating a lacZ gene flanked by a MCS. This fragment was ligated into the SmaI site of vector PSP72 (Promega), released from PSP72 by digestion with EcoRI and MunI and then ligated into the EcoRI site of pRW1p-gpdA: $\operatorname{trpC}$. The resulting vector was then restricted with HindIII and re-ligated to excise the lacZ gene, leaving the MCS in place and creating the binary vector pKR1. 
The construction of the hpGus sequence was described previously [27]. Basically, the Gus gene, which contained two EcoRV sites at 562 nt and 793 nt, was digested with EcoRV and re-ligated to remove the internal 231 nt EcoRV region. This was to prevent the expression of a functional Gus protein. This 231 bp region is therefore unique to the Gus gene and not present in the $h p G u s$ gene and was used as a template for the preparation of radioactive probes to distinguish between the hpGus and full length Gus transcripts. The resulting fragment (approximately $1.6 \mathrm{~kb}$ ) was ligated at the 3' end to a 606 bp 5' Gus fragment (up to the first HincII site of the Gus ORF) in an antisense orientation, forming an inverted repeat (or $h p G u s$ sequence) containing a approximately 560 bp complementary sequence interrupted by a $1.1 \mathrm{bp}$ Gus fragment (Figure 1). The hpGus gene was transferred from the pGEM-T Easy vector into pKR1 using EcoRI and ApaI.

To create the hpGfp construct for expression in fungi, an existing $h p G F P$ sequence was excised from vector pUQC218 [41] EcoRI digestion, end-filled with Pfu DNA polymerase, and ligated into the EcoRV site of pUS1. The resulting expression cassette was then excised using EcoRI and ligated into the EcoRI site of pRW1p to create the binary vector $\mathrm{pRW} 1 \mathrm{p}-h p G f p$. This vector mediates expression of an hpRNA that contains the $p d k$ intron in spliceable orientation (Figure 1).

The hpFrp gene was constructed in similar fashion to the hpGus gene. A long Frp fragment (nt 39-1063 of the Frp 1 gene [Genbank AY673970]) was amplified by PCR using the forward primer frp L-F with a $5^{\prime}$ terminal $A f l \mathrm{II}$ recognition site and the reverse primer frpL-R with a $5^{\prime}$ terminal HindIII recognition site. A short frp fragment was PCR amplified using the forward primer frpS-F with a $5^{\prime}$ terminal BamHI site and the reverse primer frpS-R with a $5^{\prime}$ terminal HindIII site. The two fragments were successively ligated into the AflII/HindIII and HindIII/ BamHI sites of pUS1. The cassette was released via EcoRI digestion, the overhangs filled using Pfu polymerase and the fragment ligated into the EcoRV site of vector pPZPhyg to create pPZPhyg-hpFrp (Figure 1). The 3' region (nt 1064 onward) of the frp 1 gene was not included in hpFrp and the terminal 492 nt (nt 1090 onward) were used as a template for synthesis of radioactive probes to differentiate between the hpFrp gene and endogenous Frp1 transcript.

\section{Creation of convergent promoter silencing construct}

The trpC promoter and $\operatorname{trp} \mathrm{C}$ terminator were amplified by PCR using primers trpC-PrF, trpC-PrR and trpC-TF, trpC-TR, respectively. The two fragments were combined by overlapping PCR, creating a promoter:terminator sequence (pro:ter) interrupted by ApaI and EcoRI restriction sites. After cloning into the pGEM-T Easy vector, the pro: ter fragment was transferred into the pPZPnat1 vector [GenBank:AY631958] using XbaI and Pst I to create pPZPnat-pro:ter. Then, the $1.1 \mathrm{~kb} 3$ ' region of the Gus gene was excised from a pGEM-T Easy vector carrying the Gus ORF and ligated into vector pPZPnat-pro:ter via the ApaI and EcoRI sites. Subsequently, the gpdA promoter was excised from pUS1 using BamHI and Pst I and ligated behind the $\operatorname{trp} \mathrm{C}$ terminator sequence. This was achieved such that the gpdA promoter and the trpC promoter were in convergent orientation (Figure 8). To create the final conP-Gus construct, the trpC terminator sequence was deleted through EcoRI and BamHI digestion, and the remainder of the plasmid was end-filled using $P f u$ polymerase and re-ligated (Figure 8). All plasmids were verified by sequencing prior to use.

\section{Fusarium transformation}

Transformation of Fusarium was achieved by co-cultivation of conidia with Agrobacterium adapted from [42]. AGL0 carrying the binary vector of interest was grown in $7.5 \mathrm{ml}$ of LB medium with appropriate antibiotics for two days at $28^{\circ}$ $\mathrm{C}$, the cells of $1 \mathrm{ml}$ of the culture collected by centrifugation and suspended in $20 \mathrm{ml}$ of induction media. Cells were incubated at $28^{\circ} \mathrm{C}$ for a further $6 \mathrm{~h}$. Fusarium conidiospores were grown in PDB for two days, filtered through miracloth (Calbiochem, Merck KGaA, Darmstadt, Germany) and the optical density at $600 \mathrm{~nm}\left(\mathrm{OD}_{600}\right)$ measured. The spore content was calculated using a standard curve. Conidia were collected by centrifugation at 4,000 rpm for $10 \mathrm{~min}$, suspended in water and the concentration adjusted to $1 \mathrm{E}^{6}$ spores/ml. Then, $100 \mu \mathrm{l}$ Fusarium spores were mixed with $400 \mu \mathrm{l}$ AGLO and $300 \mu \mathrm{l}$ plated on induction agar overlayed with a Hybond membrane. After $48 \mathrm{~h}$ incubation at $28^{\circ} \mathrm{C}$ the membranes were transferred onto PDA containing either $50 \mu \mathrm{g} / \mathrm{ml}$ hygromycin or $50 \mu \mathrm{g} / \mathrm{ml}$ nourseothricin as well as $100 \mu \mathrm{g} / \mathrm{ml}$ timentin, or $25 \mu \mathrm{g} / \mathrm{ml}$ phleomycin and $250 \mu \mathrm{g} / \mathrm{ml}$ of cefotaxime. Cefotaxime selection was substituted with timentin after the first round of selection. Individual transformants were transferred onto fresh selective medium. Genetically pure cultures were obtained by plating $25 \mu \mathrm{l}$ of a spore suspension $\left(1 \mathrm{E}^{3}\right.$ spores $\left./ \mathrm{ml}\right)$ on a selective plate and subsequent isolation of a star colony.

\section{DNA and RNA isolations}

To generate the biomass required Fusarium mycelium was obtained and harvested as described in [43]. For DNA isolations mycelium was ground in liquid $\mathrm{N}_{2}$ and the powder suspended in $500 \mu$ DNA extraction buffer and $50 \mu \mathrm{l}$ of $10 \% \mathrm{SDS}$ and incubated at $50^{\circ} \mathrm{C}$ for $10 \mathrm{~min}$. The DNA was extracted with $500 \mu \mathrm{l}$ phenol/chloroform and subsequently with $500 \mu \mathrm{l}$ chloroform and ethanol precipitated at $-20^{\circ} \mathrm{C}$ overnight. The pellet was washed with $75 \%$ ethanol, air-dried and the DNA suspended in TE buffer containing RNase. 
RNA was isolated using Trizol Reagent according to manufacturer's instructions and the pellets suspended in either water or formamide. DNA and RNA concentrations were measured using the NanoDrop ND-1000 (Thermo Fisher Scientific, Waltham, MA, USA).

\section{Southern blot analysis}

A total of $5 \mu \mathrm{g}$ of genomic DNA was digested overnight, the DNA phenol/chloroform purified and ethanol precipitated. The fragments were separated on a $1 \%$ agarose gel at $2 \mathrm{~V} / \mathrm{cm}$ over night. The gel was incubated in 0.25 $\mathrm{M} \mathrm{HCl}$ for $10 \mathrm{~min}$, then in $1.5 \mathrm{M} \mathrm{NaCl}$ and $0.5 \mathrm{M}$ $\mathrm{NaOH}$ for $30 \mathrm{~min}$, followed by a $30 \mathrm{~min}$ washing step in $1.5 \mathrm{M} \mathrm{NaCl}$ and $0.5 \mathrm{M}$ Tris- $\mathrm{HCl} \mathrm{pH} \mathrm{7.5.} \mathrm{The} \mathrm{DNA} \mathrm{frag-}$ ments were transferred to Hybond- $\mathrm{N}^{+}$membrane by standard capillary transfer in $20 \times$ SSC over night and then cross-linked to the membrane using a UV crosslinker (Stratagene, Agilent Technologies, Mulgrave, VIC, Australia). Pre-hybridization was carried out in SDS/BSA hybridization solution for at least $3 \mathrm{~h}$ prior to adding the probe.

Probes incorporating ${ }^{32} \mathrm{P}$-dCTP were prepared using the Megaprime DNA Labelling System (Amersham) according to manufacturer's instructions. The probes were purified using Amersham G50 columns, denatured at $100^{\circ} \mathrm{C}$ for $5 \mathrm{~min}$, kept on ice for $10 \mathrm{~min}$ and then added to the membrane. Hybridization was carried out in approximately $20 \mathrm{ml}$ SDS/BSA Hybridization solution at $65^{\circ} \mathrm{C}$ over night. Membranes were washed three times in $2 \times \mathrm{SSC}+0.1 \% \mathrm{SDS}$ for $10 \mathrm{~min}$ at $65^{\circ} \mathrm{C}$ before exposure to a Phosphorscreen.

\section{Northern blot analysis}

For mRNA northern blotting $10 \mu \mathrm{g}$ of total RNA was separated on a $1.3 \%$ agarose formaldehyde gel and the fragments transferred to Hybond-N membranes by standard $20 \times$ SSC capillary transfer over night. The RNA was cross-linked to the membrane in a UV crosslinker and the membrane pre-hybridized at $42^{\circ} \mathrm{C}$ in northern hybridization buffer for at least 3 hours. Hybridization was carried out at $42^{\circ} \mathrm{C}$ overnight and membranes were washed twice in PES buffer $(0.04 \mathrm{M}$ $\mathrm{NaPO}_{4}, 0.2 \%$ SDS and $1 \mathrm{mM}$ EDTA pH 7.2) at $65^{\circ} \mathrm{C}$ before exposure to a Phosphorscreen. For siRNA northern analysis, $15 \mu \mathrm{g}$ of total RNA were separated on a $17 \%$ polyacrylamide-urea gel and the fragments transferred to Hybond- $\mathrm{N}^{+}$membrane by electro-blotting. The RNA was cross-linked to the membrane by UV crosslinking. All hybridization and washes were carried out at $42^{\circ} \mathrm{C}$. Membranes were pre-hybridized in northern hybridization buffer for at least 3 hours prior to adding the probe. Hybridization was carried out overnight and membranes washed twice in $2 \times$ SSC $+0.2 \%$ SDS prior to exposure to a Phosphorscreen.
Probes were prepared by in vitro transcription incorporating ${ }^{32} \mathrm{P}$-UTP using the Riboprobe Combination System (Promega) according to manufacturer's instructions. Probes were precipitated with $7.5 \mathrm{M}$ ammonium acetate and suspended in $20 \mu \mathrm{l}$ TE buffer. Probes for siRNA northern analysis were treated with a carbonate solution $\left(80 \mathrm{mM} \mathrm{NaHCO} 3\right.$ and $\left.120 \mathrm{mM} \mathrm{Na} 2 \mathrm{HCO}_{3}\right)$ at $60^{\circ} \mathrm{C}$ and then precipitated with $7.5 \mathrm{M}$ ammonium acetate. Screens were developed using a Phorphorimager (FLA-5000; Fujifilm Corporation, Tokyo, Japan).

\section{Gus staining and MUG assay}

Gus activity in mycelial fractions was assessed by incubating samples with X-glucuronide solution $(0.1 \mathrm{M}$ $\mathrm{NaPO}_{4}, 10$ mM EDTA pH 7.0, 0.5 mM potassium ferricyanide, $0.5 \mathrm{mM}$ potassium ferrocyanide, $1 \mathrm{mM}$ $\mathrm{X}$-Glucuronide and $0.1 \%$ Triton $\mathrm{X}-100$ ) at $37^{\circ} \mathrm{C}$ for several hours or overnight.

For quantitative Gus activity analysis, a small sample of mycelium was obtained as described in [43] and ground with sand in 50 to $100 \mu \mathrm{l}$ protein extraction buffer for $30 \mathrm{~s}$ using a glass rod and drill. The samples were centrifuged at $4^{\circ} \mathrm{C}$ for $5 \mathrm{~min}$ and the protein concentration of the supernatant measured by standard Bradford Assay. MUG assay was performed as described previously [44] and the Gus activity determined from the slope of the curve using Excel. Gus activity in each sample was calculated relative to the total amount of protein in the cell extracts.

\section{Cleavage product identification by rapid amplification of CDNA ends (5' RACE)}

A DNA/RNA adapter was ligated to the free $5^{\prime}$ phosphates of DNase treated total RNA samples. Four $\mu \mathrm{g}$ of total RNA were incubated with 40 pmol of adapter, 50 $\mathrm{mM}$ HEPES buffer pH 7.5, $1 \mathrm{mg} / \mathrm{ml}$ BSA, $8 \%$ glycerol, RNaseOut (Invitrogen, Life Technologies Australia, Mulgrave, VIC, Australia) and T4 RNA ligase (Promega) in $1 \times$ T4 RNA ligase buffer for $2 \mathrm{~h}$ at room temperature (RT). The RNA was phenol/chloroform extracted and suspended in $12 \mu \mathrm{l}$ RNase-free water. Reverse transcription of $6 \mu \mathrm{l}$ of ligate was carried out using gene specific primers Gus-RT1 or Gus-RT2. RACE products were amplified by PCR using an adapter primer and a genespecific nested primer (Gus-RT1n or Gus-RT2n) and obtained fragments were separated by agarose gel electrophoresis. Fragments were excised from the gel, eluted using the Ultra Clean DNA Purification Kit (Mo Bio Laboratories, Carlsbad, CA, USA) and ligated into the pGEM-T Easy vector for sequencing.

\section{Reverse transcription}

Total RNA samples were treated with RNase-free DNase One to remove all contaminating genomic DNA. 
Samples were analyzed for purity by PCR of an endogenous gene prior to reverse transcription. Reverse transcription was carried out using gene-specific primers and SuperScript III Reverse Transcriptase (Invitrogen) according to manufacturer's instructions. For subsequent PCR reactions $0.5 \mu \mathrm{l}$ of $\mathrm{cDNA}$ was used as template.

\section{Creation of a lambda phage library}

The library was prepared from genomic DNA of Fusarium oxysporum line S34. The library was created using the Lambda Dash II/BamHI vector kit (Invitrogen). All steps were performed according to manufacturer's instructions. Genomic DNA was partially digested using Sau3A and size fractionated by centrifugation through a sucrose gradient. The layer containing fragments of approximately $10 \mathrm{~kb}$ size was used for ligated into the pre-digested lambda vector to create the library. Plaque lifts and subsequent DNA blotting was performed to identify phage plaques that carry Gus-specific sequences. Phage DNA from an individual pure phage lysate was extracted as described in [45]. Entire lambda phage was sequenced to determine the nature of the Gusspecific region.

\section{Sequencing}

Plasmid DNA was sequenced using Big Dye Terminator v3.1 (Applied Biosystems, Life Technologies Australia, Mulgrave, VIC, Australia) according to manufacturer's instructions. Reactions were ethanol precipitated, run using a 96 capillary 3730 DNA Analyser (Applied Biosystems) at the John Curtin School of Medical Research, Australian National University, Canberra and analyzed using the Vector NTI program suite. Sequencing of the lambda phage DNA was carried out using the Ion Torrent Platform at the John Curtin Institute, Australian National University, Canberra and analyzed using the CLC Genomics Workbench (CLC bio, Taipei, Taiwan).

\section{Additional file}

Additional file 1: Supportive information.

\begin{abstract}
Abbreviations
Dcl: Dicer-like protein; disiRNAs: Dicer-independent small interfering RNAs: dsRNA: double-stranded RNA; Frp1: Fusarium oxysporum F-box protein required for pathogenesis 1 gene; Gfp: green fluorescent protein gene; gpdA: promoter of the Aspergillus nidulans glyceraldehyde 3-phosphate dehydrogenase gene; Gus: Escherichia coli $\beta$-glucuronidase reporter gene; hpGus: $\beta$-glucuronidase hairpin RNA transgene (hpGus); hpRNA: hairpin RNA; kb: kilo base pair; MCS: multiple cloning sites; miRNAs: micro RNAs; milRNA: miRNA-like genes; MUG: 4-methylumbelliferyl-B-D-glucuronide; qiRNAs: Qde2-interacting siRNAs; RISC: RNA-induced silencing complex; siRNA: small interfering RNA; trpC: transcription termination sequence or promoter sequence of the Aspergillus nidulans tryptophan synthase gene.
\end{abstract}

\section{Competing interests}

The authors declare that they have no competing interests.

\section{Authors' contributions}

US helped design the study, carried out molecular studies and bioinformatics analyses and drafted the manuscript. NAS carried out molecular work, had intellectual input into the study design and helped draft the manuscript. KK and MA critically revised the manuscript. MA helped create the lambda library. MBW designed this study and drafted and revised the manuscript. All authors read and approved the final manuscript.

\section{Acknowledgements}

We thank Chris Helliwell for assistance with sequencing analysis of lambda clones, and Liz Dennis and Jim Peacock for support and helpful discussions. M.B.W. was supported by an Australian Research Council Future Fellowship (FT0991956).

\section{Author details}

${ }^{1}$ Commonwealth Scientific and Industrial Research Organisation Plant Industry, Clunies Ross Street, Canberra ACT 2601, Australia. ${ }^{2}$ Commonwealth Scientific and Industrial Research Organisation Plant Industry, Queensland Bioscience Precinct, 306 Carmody Road, St. Lucia QLD 4067, Australia.

Received: 3 April 2013 Accepted: 13 June 2013

Published: 2 July 2013

\section{References}

1. Moazed D: Small RNAs in transcriptional gene silencing and genome defence. Nature 2009, 457:413-420.

2. Stefani G, Slack FJ: Small non-coding RNAs in animal development. Nat Rev Mol Cell Biol 2008, 9:219-230.

3. van Wolfswinkel JC, Ketting RF: The role of small non-coding RNAs in genome stability and chromatin organization. J Cell Sci 2010, 123:1825-1839.

4. Iwasaki S, Tomari Y: Argonaute-mediated translational repression (and activation). Fly (Austin) 2009, 3:204-206.

5. Vaucheret H: Plant Argonautes. Trends Plant Sci 2008, 13:350-358.

6. Halic M, Moazed D: Dicer-independent primal RNAs trigger RNAi and heterochromatin formation. Cell 2010, 140:504-516.

7. Lee HC, Chang SS, Choudhary S, Aalto AP, Maiti M, Bamford DH, Liu Y: qiRNA is a new type of small interfering RNA induced by DNA damage. Nature 2009, 459:274-278.

8. Lee H-C, Li L, Gu W, Xue Z, Crosthwaite SK, Pertsemlidis A, Lewis ZA, Freitag M, Selker EU, Mello CC, Liu Y: Diverse pathways generate microRNA-like RNAs and Dicer-independent small interfering RNAs in fungi. Mol Cell 2010, 38:803-814.

9. Klattenhoff $C$, Theurkauf W: Biogenesis and germline functions of piRNAs. Development 2008, 135:3-9.

10. Juliano C, Wang J, Lin H: Uniting germline and stem cells: the function of Piwi proteins and the piRNA pathway in diverse organisms. Annu Rev Genet 2011, 45:447-469.

11. Eamens $A$, Wang M-B, Smith NA, Waterhouse PM: RNA silencing in plants: yesterday, today, and tomorrow. Plant Physiol 2008, 147:456-468.

12. Woolcock KJ, Gaidatzis D, Punga T, Bühler M: Dicer associates with chromatin to repress genome activity in Schizosaccharomyces pombe. Nat Struct Mol Biol 2011, 18:94-99.

13. Emmerth $\mathrm{S}$, Schober $H$, Gaidatzis D, Roloff T, Jacobeit K, Bühler M: Nuclear retention of fission yeast dicer is a prerequisite for RNAi-mediated heterochromatin assembly. Dev Cell 2010, 18:102-113.

14. Simmer F, Buscaino A, Kos-Braun IC, Kagansky A, Boukaba A, Urano T, Kerr ARW, Allshire RC: Hairpin RNA induces secondary small interfering RNA synthesis and silencing in trans in fission yeast. EMBO Rep 2010, 11:112-118.

15. Nakayashiki $\mathrm{H}$, Kadotani $\mathrm{N}$, Mayam S: Evolution and diversification of RNA silencing proteins in fungi. J Mol Evol 2006, 63:127-135.

16. Nakayashiki H: RNA silencing in fungi: mechanisms and applications. FEBS Lett 2005, 579:5950-5957.

17. Camblong J, Beyrouthy N, Guffanti E, Schlaepfer G, Steinmetz LM, Stutz F: Trans-acting antisense RNAs mediate transcriptional gene cosuppression in S. cerevisiae. Genes Dev 2009, 23:1534-1545.

18. Camblong J, Iglesias N, Fickentscher C, Dieppois G, Stutz F: Antisense RNA stabilization induces transcriptional gene silencing via histone deacetylation in S. cerevisiae. Cell 2007, 131:706-717.

19. Nicolás FE, de Haro JP, Torres-Martínez S, Ruiz-Vázques R: Mutants defective in a Mucor circinelloides dicer-like gene are not compromised in siRNA 
silencing but display developmental defects. Fungal Genet Biol 2006, 44:504-516.

20. de Haro JP, Calo S, Cervantes M, Nicolás FE, Torres-Martínez S, Ruiz-Vázquez RM: A single dicer gene is required for efficient gene silencing associated with two classes of small antisense RNAs in Mucor circinelloides. Eukaryot Cell 2009, 8:1486-1497.

21. Nakayashiki H, Hanada S, Bao Quoc N, Kadotani N, Tosa Y, Mayam S: RNA silencing as a tool for exploring gene function in ascomycete fungi. Fungal Genet Biol 2005, 42:275-283.

22. Nakayashiki H, Nguyen QB: RNA interference: roles in fungal biology. Curr Opin Microbiol 2008, 11:494-502.

23. de Backer MD, Raponi M, Arndt G: RNA-mediated gene silencing in non-pathogenic and pathogenic fungi. Curr Opin Microbiol 2002, 5:323-329.

24. Schumann U, Ayliffe M, Kazan K, Wang MB: RNA silencing in fungi. Front Biol 2010, 5:478-494.

25. Sigova A, Rhind N, Zamore PD: A single argonaute protein mediates both transcriptional and posttranscriptional silencing in Schizosaccharomyces pombe. Genes Dev 2004, 18:2359-2367.

26. lida T, Nakayama J-I, Moazed D: siRNA-mediated heterochromatin establishment requires HP1 and is associated with antisense transcription. Cell 2008, 31:178-189.

27. Wang MB, Waterhouse PM: High-efficiency silencing of a beta-glucuronidase gene in rice is correlated with repetitive transgene structure but is independent of DNA methylation. Plant Mol Biol 2000, 43:67-82.

28. Wang MB, Helliwell CA, Wu LM, Waterhouse PM, Peacock WJ, Dennis ES: Hairpin RNAs derived from RNA polymerase II and polymerase III promoter-directed transgenes are processed differently in plants. RNA 2008, 14:903-913.

29. Duyvesteijn RGE, van Wijk R, Boer Y, Rep M, Cornelissen BJC, Haring MA: Frp1 is a Fusarium oxysporum F-box protein required for pathogenicity on tomato. Mol Microbiol 2005, 57:1051-1063.

30. Jonkers W, Rodrigues CD, Rep M: Impaired colonization and infection of tomato roots by the Deltafrp1 mutant of Fusarium oxysporum correlates with reduced CWDE gene expression. Mol Plant Microbe Interact 2009, 22:507-518.

31. Yan J, Gu Y, Jia X, Kang W, Pan S, Tang X, Chen X, Tang G: Effective small RNA destruction by the expression of a short tandem target mimic in Arabidopsis. Plant Cell 2012, 24:415-427.

32. Baccarini A, Chauhan H, Gardner TJ, Jayaprakash AD, Sachidanandam R, Brown BD: Kinetic analysis reveals the fate of a microRNA following target regulation in mammalian cells. Curr Biol 2011, 21:369-376.

33. Palauqui JC, Elmayan T, Pollien JM, Vaucheret H: Systemic acquired silencing: transgene-specific post-transcriptional silencing is transmitted by grafting from silenced stocks to non-silenced scions. EMBO J 1997, 16:4738-4745.

34. Mette MF, Aufsatz W, van der Winden J, Matzke MA, Matzke AJ: Transcriptional silencing and promoter methylation triggered by double-stranded RNA. EMBO J 2000, 19:5194-5201.

35. Goldoni M, Azzalin G, Macino G, Cogoni C: Efficient gene silencing by expression of double stranded RNA in Neurospora crassa. Fungal Genet Biol 2004, 41:1016-1024.

36. Smith NA, Singh SP, Wang M-B, Stoutjesdijk PA, Green AG, Waterhouse PM: Total silencing by intron-spliced hairpin RNAs. Nature 2000, 407:319-320.

37. Smith LM, Pontes O, Searle I, Yelina N, Yousafzai FK, Herr AJ, Pikaard CS, Baulcombe DC: An SNF2 protein associated with nuclear RNA silencing and the spread of a silencing signal between cells in Arabidopsis. Plant Cell 2007, 19:1507-1521

38. Covert SF, Kapoor P, Lee M-H, Briley A, Nairn CJ: Agrobacterium tumefaciens-mediated transformation of Fusarium circinatum. Mycol Res 2001, 105:259-264

39. Houterman PM, Cornelissen BJ, Rep M: Suppression of plant resistance gene-based immunity by a fungal effector. PLoS Pathog 2008, 4:e1000061.

40. Punt PJ, Oliver RP, Dingemanse MA, Pouwels PH, van den Hondel CA: Transformation of Aspergillus based on the hygromycin B resistance marker from Escherichia coli. Gene 1987, 56:117-124.

41. Brosnan CA, Mitter N, Christie M, Smith NA, Waterhouse PM, Carroll B: Nuclear gene silencing directs reception of long-distance mRNA silencing in Arabidopsis. Proc Natl Acad Sci USA 2007, 104:14741-14746.
42. Takken FL, Van Wijk R, Michielse CB, Houterman PM, Ram AF, Cornelissen BJ: A one-step method to convert vectors into binary vectors suited for Agrobacterium-mediated transformation. Curr Genet 2004, 45:242-248.

43. Schumann U, Smith NA, Wang MB: A fast and efficient method for preparation of high-quality RNA from fungal mycelia. BMC Res Notes 2013, 6:71.

44. Chen S, Helliwell CA, Wu LM, Dennis ES, Upadhyaya NM, Zhang R, Waterhouse PB, Wang MB: A novel T-DNA vector design for selection of transgenic lines with simple transgene integration and stable transgene expression. Funct Plant Biol 2005, 32:671-681.

45. Sambrook J, Fritsch EF, Maniatis T: Molecular cloning: a laboratory manual. 2nd edition. New York: Cold Spring Harbor Laboratory Press; 1989.

doi:10.1186/1758-907X-4-3

Cite this article as: Schumann et al: Analysis of hairpin RNA transgeneinduced gene silencing in Fusarium oxysporum. Silence 2013 4:3.

\section{Submit your next manuscript to BioMed Central and take full advantage of:}

- Convenient online submission

- Thorough peer review

- No space constraints or color figure charges

- Immediate publication on acceptance

- Inclusion in PubMed, CAS, Scopus and Google Scholar

- Research which is freely available for redistribution 